\title{
'SALIMU': FROM MEMORY TO LITERARY NARRATIVE IN TWENTIETH-CENTURY MANDING CULTURE
}

\author{
Tal Tamari \\ Centre National de la Recherche Scientifique, France
}

\begin{abstract}
This essay explores the creation of new literary narratives, many inspired by true incidents, from the late nineteenth century to the present, among Manding- (specifically Maninka-) speakers in Mali and Guinea. It simultaneously queries the relationships between Manding and Western literary categories, showing that the traits typically associated with African 'epics' - including poetic language, alternation of sung and recited passages to continuous instrumental accompaniment, and multi-generic qualities - characterise some (but not all) examples of several distinct Manding literary categories (fasa, tariku and maana); furthermore, these traits appear in narratives of various lengths, centred on sentimental as well as heroic themes. It then focuses on the stories and songs inspired by the apparently contradictory personality of Salimou Haidara (ca. 1930-1991), an eccentric who claimed sharifian descent. A performance by Amadou Kouyaté and Jekoriya Doumbia, a bard couple based in the village of Dabadou near Kankan (Guinea), is transcribed, translated, and analysed ${ }^{1}$.
\end{abstract}

KEYWORDS: EPIC, LITERARY GENRE, GRIOTS, MANINKA, KANKAN (GUINEA), CHEIKH MOUHAMMAD CHÉRIF

\section{Introduction}

The Manding-speaking peoples are famed for their oral literary heritage, which includes a variety of narrative, lyrical, and theatrical forms. Narratives associating sung and spoken passages, performed to musical accompaniment, which have been identified as 'epics', have attracted the greatest attention, but there are also folktales and riddles (nsiirin in Bamana, taali in Maninka, ntalen in some forms of Jula), proverbs (sanda, ntalen), a diversity of songs (dònkili), hunters' epics (donso maana), the kòtèba (farcical theatrics and dancing), as well as dramatic and lyrical performances associated with traditional, more rarely Islamic, rituals. ${ }^{2}$ Best-known are the Sunjata 'epic' (which purports to re-

1 I am grateful to Kèlètigui Doukouré, history instructor at the University of Kankan, for introducing me to Amadou Kouyaté and Jekoriya Doumbia. He is the person referred to in line 162 (pp. 25 and 35) of their narrative.

2 For an overview of Manding oral literature, see e.g. Derive 1986, 2012. I have personally witnessed the theatrelike public performances of several Bamana initiation societies (which, I am furthermore told, are in certain cases quite similar to those restricted to initiates only). The genealogical commemorations that are sometimes associated with Muslim holidays may take on a theatrical dimension. In the analytical sections of this paper, names of historical or living persons, as well as geographical names, are cited, whenever possible, in accordance with their official (French-influenced) spellings. In contrast, in the translation, all proper names are given in their 
count the founding of the Mali empire in the thirteenth century), the Segu 'epic', which relates to the Bamana-dominated empire that flourished from the early eighteenth to the mid-nineteenth century, and those that relate to the Mandinka-speaking kingdoms that stud the Gambia river. ${ }^{3}$

In the course of field research, the present writer came to realise that new oral tales had been created in Mali and Guinea at least through the mid-twentieth century, and that these had most of the stylistic characteristics that Western researchers have attributed to 'epics' in the Manding, and more generally West African, context. These narratives - as well as some songs sung in a traditional style - not only provide clues as to how recollected events are transformed into literary creations but may also contribute to a better understanding of how Manding themselves categorise the different works that together constitute their oral literary heritage.

After briefly evoking several twentieth-century creations, this essay will focus on a particular work - 'Salimu', on the frontier of two Manding literary genres, story (maana / tariku) and song (dònkili). It will analyse the social and cultural contexts in which it came into being, and the values it implicitly or explicitly conveys. Finally, it will present the transcription and translation of a particular performance.

\section{'Epic' as a Literary Genre in West Africa}

Almost forty years ago, J.W. Johnson (1980; discussion expanded and updated in Johnson 2003 [1986] pp. 30-57) considerably advanced discussion of African literary genres by providing what has become a widely accepted definition of African, and especially, West African and Manding epic. According to him, epic in Africa is characterised by eight criteria. Chief among them are poetic language, including an alternation between 'song' and 'narrative' modes (sung and spoken passages), both articulated to instrumental accompaniment; narrative content (thus distinguishing it from praise songs and panegyric); and multi-generic qualities (in the sense that each 'epic' includes examples of the other recognised Manding literary genres).

Several writers have glossed the meaning of poetic language - whether with respect to Johnson's or other definitions - stressing qualities such as a sophisticated linguistic register, rare, archaic, or specifically 'literary' vocabulary, considerable use of imagery, and specific prosodic techniques (such as meter, rhyme, or in an African context, tonal rhyme). ${ }^{4}$

J.W. Johnson's requirement that epics be 'lengthy' has, understandably, led to some controversy - since length is, as he himself points out, a relative concept. While the 'political epics' studied by Johnson and other early researchers may require up to several hours to

Manding spellings (or nearest English equivalents), as are names of literary figures and titles of literary works in the analytical sections. Since Salim (or Salimou) Haidara is both a historical and literary figure, his name is given, after an initial presentation, in accordance with Manding spelling (Salimu).

3 See especially: Niane 1960, Innes 1974, Cissé 1988, 1991, Conrad 2004; Dumestre and Kesteloot 1975, Dumestre 1979, Conrad 1990; Innes 1976, Sirifo Camara and Sana Camara 2010. 
perform, and a specific episode or sequence devoted to a particular hero may require forty minutes to an hour, some researchers have claimed that even a ten minutes' narrative poem could be considered an epic, provided that it displayed the other stylistic characteristics associated with this genre. ${ }^{5}$

The 'heroic' character of African epics has been progressively nuanced, both by Johnson and others. While all narratives referred to as 'epic' have a clearly identified protagonist or set of protagonists, narratives studied by the early researchers focused on kings, wars, and state-building. Johnson and some later writers have come to qualify these as 'political epics', which they contrast with those based on sentimental themes. 'Sara', an entirely sung narrative of about ten minutes' duration, which tells of how a young girl successfully refuses the husband her family has chosen for her in favour of the one she loves, is an example of a literary work that has been qualified as 'epic', though it is neither long nor heroic (in a classical sense). ${ }^{6}$ Most of the twentieth-century creations discussed below can also be qualified as 'sentimental' in focus, though they come closer to meeting the length requirement.

Johnson, and many other researchers - whether working on Africa or other regions of the world - have stressed the 'legendary' character of epic, i.e., the culturally held belief in its historicity. While these writers have generally also insisted on the discrepancies between epic accounts and information about the past as it may be derived from other sources ${ }^{7}$, it may be more fruitful to stress that, in West African and most other contexts, these works usually have some basis in past reality, and that their protagonists correspond to onceliving (or in some instances, still-living) persons. ${ }^{8}$ This is indeed a striking characteristic of each of the narratives and songs discussed below.

Johnson stresses that epics are 'multi-functional', in the sense that they fulfil several key societal functions - in the case of the Sunjata epic, creating and preserving a feeling of 'national' (or should one say 'cultural'?) unity, and providing role models for transmitters and listeners. However, this is also true, though perhaps to a lesser extent, of other oral literary genres. Nevertheless, it is remarkable that all the works discussed below address and provide ways of thinking through moral dilemmas, several of which could only have arisen (in the specific forms evoked) in twentieth- and twenty-first century social conditions. ${ }^{9}$

5 Charles Bird and Kassim Koné, 'Sara', in Johnson, Hale, and Belcher, eds., 1997, pp. 114-123.

6 Bird and Koné ibid.

7 Johnson 1980, 2003 (1986), pp. 3-7, 41-47, Innes 1974, pp. 1-2, 25-27.

8 Wilks 1999. I had presented similar arguments in my doctoral thesis (1988, pp. 139-165, published 1997, pp. 266-283). Georges Dumézil, who proved that both the Sanskrit epics and the Roman 'histories' grew largely out of representations concerning the sacred (i.e. mythology), recognised that they also included references to past events as well as real geographical sites. See especially his Mythe et épopée [Myth and Epic] (1995; first ed. 1968-1973).

9 Jansen, Counsel and Camara 2018 focus on how a song, set in the 1950s but recorded considerably later (the video version analysed dates from ca. 1987) addresses twentieth-century social issues. The role of oral literature in helping performers and auditors resolve contemporary moral dilemmas is also a major theme of Tamari 2009 and 2011. 
'Cultural and traditional transmission' is the last of the eight criteria stipulated by Johnson for defining African epic. By this, he means that epics transmit culturally significant information. This is, of course, true. However, in a West African and especially Manding context, it may be more useful to place emphasis on other factors suggested by this label. All the oral literary works that have been categorised as 'epics', in the Sudanic and Sahelian zones - among the Manding, but also Soninke, Wolof, Fulbe, Songhay and others are transmitted exclusively by endogamous hereditary bards, who master them through a lengthy and highly codified apprenticeship process. These bards or 'griots' usually study, for years, with their own relatives; some of them may then go on study tours, travelling to learn with more distant relatives and visiting historical sites. ${ }^{10}$

Editions by Johnson (2003, $1^{\text {st }}$ ed. 1983), Innes (1974, 1976), Conrad (1990, 2004), Sane Camara (2010) and others ${ }^{11}$ leave little doubt that an oral literary genre that corresponds quite closely to Western concepts of epic exists in Manding and other West African societies. What is less clear, however, is whether the Manding recognise these works as constituting a specific literary genre, or whether this concept is being applied to narratives that Manding categorise in some other way(s).

On the basis of an analysis of the terms Manding-speakers use for describing discourse and designating different oral literary works, I lean to the view that 'epics' constitute a subset (not recognised by the Manding as such) of several other literary genres; these other genres are explicitly distinguished in the Manding languages.

Several Western researchers have suggested that the Manding term maana best corresponds to the Western concept of epic. ${ }^{12}$ This term is indeed generally used to refer to the 'Segu epic' (Segu maana). However, maana is rarely employed in connection with the Sunjata epic, which is usually referred to as the Sunjata fasa. Moreover, the term maana (at least in Malian usage) is a very general one, that can refer both to a literary recounting by a professional bard and to an unadorned narrative told by an elder or group of elders; both to a lengthy story, and to brief anecdotes - including examples embedded in a lengthier narrative that Western researchers might describe as an 'epic' ${ }^{13}$ Clearly, then, the term maana is much broader in scope than 'epic'.

On the other hand, while the term fasa is indeed applied to the Sunjata cycle considered as a whole, it is also used to designate praise poems - including those of particular heroes evoked in the Sunjata and Segu cycles. It may be hypothesised that exceptionally, in the case of the culturally emblematic and probably ancient Sunjata fasa, a term that usually designates praise poems was extended to the narrative as a whole.

Among the Maninka of Guinea - as I discovered in the field - the term tariku, rather than

10 Concerning the status of bards in general, see Sory Camara (1992, 1st ed. 1976), Hoffman 2000, Schulz 2001, and Tamari 1997. Concerning the transmission of knowledge among bards, see especially Niane 1960, pp. 5-7, English translation 1965, pp. vii-viii, Bird 1971, Cissé 1988 and 1991, and the films by Durán, 2012, 2015.

11 Including Cissé 1988, 1991, Dumestre and Kesteloot 1975, Dumestre 1979, Seydou 1972, 1976, 2014a, 2014b, Bornand 2005.

12 Bird 1976, Johnson, Hale and Belcher 1997, pp. xviii-xix, Belcher 1999, pp. 91, 214, 217, 219. See also Durán 2007, esp. pp. 578-580.

13 These themes are developed in some detail in Tamari 2007. 
maana, is generally used to designate long stories. As with some maana, these stories specifically, those that Western scholars assimilate to epics - associate sung and spoken passages, performed to instrumental accompaniment. For example, performances relating to Sunjata, or to the ancient Wagadu empire ${ }^{14}$, which in Mali are said to be fasa or maana, are labelled tariku in Guinea. According to some bards, in both Guinea and Mali, there is a distinction to be drawn between maana and tariku: the former applies to stories that have no factual basis or have a strong imaginary component (such stories being, however, rather few), whereas the latter designate those that are based on known incidents (even though some details may not be strictly true). Furthermore, it appears that the Guinean concept of tariku is more restricted than the Malian concept of maana, inasmuch as it does not apply to brief anecdotes (whether or not they are embedded in a longer narrative).

One Guinean bard categorised all the longer narratives he performed to musical accompaniment - both those he qualified as maana (imaginary) and those he qualified as tariku (true) - as 'histoires' (borrowing a French word which, perhaps significantly, refers to both imaginary 'tales' and histories). Interestingly too, this Guinean griot provided me with only one example of what he considered a fictional tale - using the French word 'fiction'. He specified that the events in question might have happened, because they were grounded in an indubitable social reality - namely, feminine duplicity and infidelity - but that they were not positively known to have occurred..$^{15}$

Though it thus appears that Manding do not terminologically distinguish between narratives with a political and with a sentimental focus, they patently distinguish a special category of stories centred on hunters' exploits and relationships to the animals and supernatural beings of the bush: the donso maana, an expression usually translated as 'hunters' epics'. ${ }^{16}$ While shorter than most of the 'political epics', many of them are about an hour in the telling. And similar to other long stories considered here, they associate sung and recited passages.

One may speculate as to why this category of oral literary works is terminologically distinguished in at least some of the Manding languages. Of course, it does have a highly specific subject matter. But several other factors may also be involved. Hunting, which

'Wagadu' is the Soninke name of the Soninke-dominated empire known in the medieval Arabic (and therefore Western) sources as 'Ghana'; it may have flourished from about 400 to 1400 A.D. (from about 1230 on, as a kingdom subordinate to the Mali empire), Arabic sources mention it from about 800 to 1350 A.D. Soninke-speakers have their own, highly codified oral traditions about this empire (see especially Monteil 1953, Bornand 2005), but as I discovered in the field, some Maninka-speaking bards also recite stories relating to this empire.

Here the bard is pointing towards a distinction similar to the one drawn by Aristotle in his Poetics, between historical and poetic truth. However, Aristotle ranked poetic truths higher than empirical, historical ones, whereas most Manding bards accord priority to the latter. This Guinean bard is exceptional in appearing to assign them equal value.

16 They are more simply rendered in French by 'récits de chasseurs', i.e. 'hunters' tales'. The more remarkable animals mentioned in the stories are credited with supernatural powers; in some instances, they are believed to be supernatural beings who have taken on animal shape. For examples of the donso maana, see e.g. Bird, Koita, and Soumaoro, eds., 1974, Thoyer-Rozat 1978, B. Camara 1998, Derive and Dumestre, eds., 2000, Traore 2000, Sidibé 2007. 
is largely carried out in the context of highly structured regional associations, once had considerable military and economic significance. ${ }^{17}$ Perhaps most importantly, these hunters' tales are not usually performed by jeli, and correlatively, are musically distinct - with different musical instruments, melodic patterns, and rhythms. In Mali at least, they are most commonly (or exclusively?) performed by members of the 'blacksmith' (numu) social category. ${ }^{18}$

That a Guinean bard, with a limited command of French, uses two French words, 'histoires' and 'fiction', to describe the stories he performs, suggests that he is searching for words to express distinctions that he perceives, and that may indeed be more widely felt by Manding-speakers, but for which the generally rich Manding language has not yet created specific designations. The widely used terms maana, tariku, and fasa-probably all of Arabic etymology - may represent earlier attempts to adapt foreign words to express Manding literary categories. ${ }^{19}$

\section{Literary Creation Since the 1890s}

Fieldwork carried out mainly between 2005 and 2012, in Mali and Guinea, has led to the collection - in addition to variants of the Wagadu and Sunjata 'epics' - of one or more renderings of the following narratives, all characterised by alternating sung and spoken passages, poetic language, musical accompaniment, and multi-generic qualities. These are:

- 'Faranyiran', a love story set in the first decades of the twentieth century, primarily in the city of Kindia, in southern Guinea;

- 'Mali Sajo', based on events that took place in the first decade of the twentieth century in Bafoulabé, Mali ${ }^{20}$;

- 'Mamadu Butigi' ('Mamadou the shopkeeper'), the story of a wealthy playboy who was based, in the first decades of the twentieth century, in Kouroussa, northern Guin$\mathrm{ea}^{21}$;

- 'Balakè', which tells of how a poor but charming boy married a wealthy woman, in early twentieth-century Guinea;

17 See especially Cissé 1964, 1994. Hunters' associations conserve considerable political and military significance, sometimes in transformed ways; see especially Hellweg 2011, Kedzierska-Manzon 2014.

18 Bird, Koita, and Soumaoro, eds., 1974, Thoyer-Rozat 1978.

19 Maana derives from the similarly pronounced Arabic macna ('meaning'), while tariku or tarixu (depending on dialect) derives from the Arabic ta'rikh ('chronicle', 'date', 'history'), itself of ultimately Aramaic derivation. Fasa likely derives from the Arabic root fsh, 'to be eloquent' (see Lagarde in Bailleul 2007, p. 284, Lagarde 1988, pp. $7,12,17,23)$.

20 This story has inspired a long narrative poem (in French) by the writer and politician Fily Dabo Sissoko (ca. 1897-1964), who had an intimate knowledge of the history and oral traditions of this region, to which he was native: 'L'Hippopotame de Bafoulabé', pp. 15-19 in Sissoko 1970. There are also two reconstructed versions for juvenile audiences, by A.E. Sissoko (not a relative of the former; 2005) and Doumbi-Fakoly (pseudonym), 2006. A cement sculpture of the hippopotamus now stands near the Bafoulabé town centre.

21 A brief version of this narrative has been published by Jan Jansen (1995). 
- 'Sunba', a story of star-crossed lovers ${ }^{22}$, which I have traced back to events that took place during the Samorian wars, in the Mande country on the borderland of Mali and Guinea;

- and 'Salimu', which tells of the exploits of a drunken but sympathetic driver, mostly in the 1950s and 1960s, in both Mali and Guinea.

Although most of these stories recount events that are set in either Mali or Guinea, they are told in both countries, mainly by Maninka-speaking bards. With the exception of 'Salimu' and 'Mamadu Butigi', of which I collected versions that are twelve to fifteen minutes long, and 'Faranyiran', of which I collected a version that was twenty minutes long, the other performances ('Mali Sajo', 'Balakè', 'Sunba', and a second performance of 'Faranyiran') were thirty minutes to over an hour long - depending on the performer rather than the story. All were categorised, by both bards and listeners, as maana in Mali and tariku in Guinea. However, some Malian bards only perform abridged, entirely sung versions, of 'Sunba', 'Mali Sajo', and 'Salimu', which both they and their audiences describe as 'songs' (dònkili).

In addition, I collected two long, entirely sung narratives - based on true incidents - that were created in twentieth-century Guinea: 'Tigibiri Solo', based on a tragic love story, culminating in the death of both lovers, that took place in the village of Tiguibiri, northern Guinea, in early colonial times; and 'Wulukoro', which tells of the tragic drowning of a young girl during a flash flood, in the 1950s, also in the Maninka country of northern Guinea. Both 'Wulukoro' and 'Tigibiri Solo' are unanimously qualified as dònkili. Though some versions are only a few minutes long, 'Wulukoro', at least, may be sung for up to an hour (including repeat passages).

Several short, published songs are known to be - or in some cases, appear likely to be - based on particular incidents. ${ }^{23}$ It may be hypothesised that a considerable proportion - but not all - of the Manding repertory originates in specific incidents that have struck a deep psychological or social chord. These works may have been created by a particular composer, or an initially small number of composers and transmitters, with further changes introduced later on as a result of wider diffusion. In most instances, details of date, place, and personal names have been forgotten over the years - conferring on them a certain generic, 'timeless' quality.

As the above implies, there is a certain permeability between narrative (maana and tari$k u$ ) and lyrical genres (dòkili). Not only does a considerable percentage of the lines of a 'narrative' consist in lyrics, but some protagonists are the subjects of both narratives and briefer, autonomous songs. Some bards may perform only narratives, or only songs, about a given hero, while yet others - as exemplified by the two renderings of 'Salimu' presented here - may perform both. Though some of the narratives may have originally

22 See Tamari 2005.

23 For example, the song in which a woman mourns her only son, killed in the 1915 'revolt of the Beledugu' (an uprising of the Bamana population of that rural region against the French who were recruiting soldiers to serve in World War I): Brévié 1917, English translation in Hale and Sidikou 2014, pp. 257-262; and several girls' initiation songs in Luneau 1974, pp. 451-458, 461-463, and also in Luneau 1981, pp. 21-39. 
developed by accretion around the songs, it would appear that at a later phase, lyrics may become detached from the narratives, pursuing autonomous trajectories of diffusion. While certain lines are common to nearly all versions, there is also considerable innovation and variation, so that no two bards perform identical narratives and that lyrics also are characterised by considerable variation.

The above data strongly suggest that Manding culture draws a clear conceptual distinction between narrative genres (including those that incorporate songs) and lyrical ones, inasmuch as all versions that include both sung and spoken passages are said to be maana or tariku, whereas those that are entirely sung are described as donkili. ${ }^{24}$

On the other hand, no terminological distinction is drawn between narratives that focus on political and military events, and ones that focus on individual - sentimental or psychological - dilemmas. Maana and tariku are considerably broader in scope than 'epic', and seamlessly englobe political as well as sentimental storylines, artistically recited and plain narratives. Elaborate, extended narratives imply the presence of songs (dònkili), but even long songs (dònkili) do not necessitate the adjunction of spoken narrative.

The relatively recent periods to which the songs and stories refer (ca. 1890-1990) might suggest that they constitute a recent or emergent literary genre. However, it is far more likely that most stories, after a limited period of popularity, perhaps linked to a living memory of events in certain milieux, are eventually forgotten, or lose all reference to a specific time and place. This point requires further research, but it is corroborated, for example, by listeners' and bards' statements to the effect that certain tales were widely told at a certain time, only to fall out of favour later.

It may be noted that the above, orally transmitted stories and songs have made a considerable contribution to the development of 'modernised' art forms and to the emergence, in Guinea, of a sense of national culture. Thus, the Guinean writer Fodéba Keïta (19211969) composed a French theatrical sketch that draws directly on Maninka oral tradition about the Tiguibiri events (above, p. 6) ${ }^{25}$, while choreographing a large number of Maninka tales for the 'Ballets africains', the Guinean national dance company. ${ }^{26}$ 'Sunba', 'Wulukoro', 'Salimu', and 'Mali Sajo' have become the subjects of very popular songs, relayed on (or specially arranged for) radio and television, while 'Sunba', 'Tigibiri', and 'Wulukoro' have been made into films. ${ }^{27}$

We now develop some of the above points, through a closer analysis of one of the works collected.

24 Many folktales (nsiirin, ntalen) include sung passages. See, e.g., Travélé 1923, Diarra and Görög 1979, Derive and Derive 1980, Sory Camara 1981. It would seem, therefore, that elaborate story-telling requires song, but that the converse is not true.

25 'Minuit', pp. 59-65 in Keita 1994 (first published 1952).

26 For a photographic record of these Ballets, see for example Huet 1954. Some of the ballet performances were recorded by Guinean national radio and television; the corresponding soundtracks have recently become available in the digital collections of the British Library (see the Sound and Moving Image Catalogue, as well as the Endangered Archives projects).

See Tamari 2009, 2011. 


\section{A Recent Literary Creation: 'Salimu'}

The performance of 'Salimu' studied here was collected from a husband-and-wife team in the village of Dabadou, situated a few kilometers outside Kankan. They first performed the story (twelve minutes), then a song version (three and a half minutes). A second narrative version was collected from a rural bard in Mali, while brief (three to five minute), entirely lyrical versions have been sung by renowned musicians such as Bako Dagnon, Mangala Camara, and Salif Keita. ${ }^{28}$

While Amadou Kouyaté and his wife Jekoriya Doumbia are generally perceived to be a bard couple, belonging to the hereditary category of jeli, their situation is more complex. Amadou Kouyaté, the husband, belongs, as his jamu or 'honourable' name suggests, to a hereditary bard lineage. However, he states that his parents had forsaken all musical and other characteristic activities of griots in order to improve their social status. Nevertheless, Amadou Kouyaté felt himself strongly attracted to music, and despite initial parental opposition, in early adulthood he studied with performing musicians (mostly of bard status), mastering both the ngoni (a traditional four-stringed instrument) and the guitar. Both these instruments are mentioned in his rendering of 'Salimu'. Amadou Kouyaté, who also farms, has an unusually large repertoire, and after each performance, would entice me to collect additional items by singing or reciting a few lines from another tale.

His wife, Jekoriya, is from a non-bard family. She learned how to sing in order to accompany him, a role in which she rapidly excelled, and now few persons are aware that she is of a non-bard background. Their children - ranging up to their late teens at the time the present performance was recorded, in January 2012 - are also musically proficient, and sometimes joined in with their parents to form a chorus. Several are now successful, independent musicians.

While marriage between hòròn 'nobles' and jeli 'bards' (as well as with certain other specialist groups) was traditionally prohibited, and is still a cause of familial dissension, it seems that a growing number of couples are braving the old rules. ${ }^{29}$

The traditional division of labour between male and female artists is respected in this performance: the former provides the narration and instrumental accompaniment, while the latter participates in the singing. Thus, in the narrative version, the male bard is responsible for conveying the storyline, enunciates all recited passages, and also does some singing, while the female bard interprets lyrics only. It will be noted that about $45 \%$ of the lines are sung (111 out of 245 , the remainder being recited). The male bard performs 47 lyrical lines, compared to the female musician's 43; 21 lines are enunciated jointly. Amadou Kouyaté's total lines are 202, compared to Jekoriya's 64 (including, in each case, lines jointly enunciated by both singers). In the second, wholly lyrical version, the

28 Excerpts from these songs, and some biographical information, is also available on the internet. See www. chantshistoiremande.free.fr. The literary critic and specialist in comparative literature Cheick Chérif Keïta (2001) has authored a major biography of Salif Keita, a relative whom he has known since childhood. Bako Dagnon figures prominently in Lucy Durán's 2012 film; passages from this film were later excerpted as a memorial tribute to this artist. 
relative contributions of the two singers are reversed, with Jekoriya singing 30 out of 56 lines, the couple jointly enunciating 11 lines, and Amadou singing the remaining 15. ${ }^{30}$ The high percentage of sung verses underscores how close, in some respects, the narrative performance of 'Salimu' is to dònkili, while a broader comparison brings out several major differences between the narrative and wholly lyrical renderings: the former has a progressive plot structure, completely absent in the latter; there is considerably more sequential repetition in the lyrical version; most, but not quite all, of the lines of the song also figure in the preceding narrative version (the exceptions being 1.19 and 38).

The narrative and associated songs are named for their protagonist, Salim Haidara, who was born in the village of Lorombo (administrative sub-region of Cisséla), about 120 $\mathrm{km}$ northwest of Kankan, in the Maninka country of northern Guinea, in the 1930s. He became famous, in the 1950s and 1960s, for his drunken but (usually) accident-free driving. As a professional driver, he transported goods and passengers throughout Guinea, as well as between Mali and Guinea. He spent his last years, in which he was unable to work, in Kankan, staying in housing arranged by a sister, and passed away in 1991. While some biographical information is included in the narrative - Salimu's links to Lorombo and Kankan, his drunken driving - all data were checked and considerably amplified through interviews with eyewitnesses (including friends, neighbours and acquaintances in Kankan).

Salimu's passion for liquor was rendered all the more remarkable by the fact that he belonged to a family claiming descent from the Prophet, as indicated by his last name. 'Haidara' (meaning 'lion', an epithet of Ali, the fourth caliph and son-in-law of the Prophet) is the family name borne by sharifs (descendants of the Prophet) in Morocco and some regions of West Africa. Much of the drollery of both song and storied versions stems from the incongruity of his sharif status - for Islam condemns virtually all alcohol consumption - and his personal behaviour.

Even more remarkable, given his sharif status, was his affiliation to the Catholic Church - a circumstance never mentioned in the songs and narratives dedicated to him. ${ }^{31}$ Yet members of the local Catholic church affirm that he attended Sunday services regularly, especially in his later years. Salimu converted to Catholicism as an adult, and regularly defended his preference for this faith. He was buried, in the course of a religious ceremony, in the Catholic cemetery adjacent the church in Kankan. His Catholic affiliation did, of course, allow him to relativise the moral failing represented by his drinking.

However, if one is to believe the bards and other persons who knew him, neither his drinking nor other 'immoral' behaviour ever led to a calling into question of his Haidara status. Nor did the circumstances of his birth: although his mother was a Haidara, his

30 In the first half of the twentieth century, nearly all famous bards were men, whose performances privileged narrative; most better-known contemporary bards, at least in Mali, are female, admired for their singing. This gradual rise to prominence of female bards is itself correlated to the increasing attention accorded to lyrics, at the expense of narrative. See, for example, Durán 2007.

31 Perhaps because this would have been too scandalous. This might have also lessened interest in him, since for the past several decades, the Manding- (Maninka- and Bamana-) speakers of Guinea and Mali have been almost exclusively Muslim. 
father - some claim - was of Lebanese origin. Given his father's foreign origin, he was allowed to take his mother's name. ${ }^{32}$ Although he never married (or was only briefly married), an adult son and daughter travelled from Bamako and Abidjan respectively to mourn him after his death. The fun of this particular version of the narrative is furthermore accentuated by the references to a revered Muslim scholar of similarly sharifian lineage - here designated as 'Sekuba of Sharifula' or 'Sekuba of Kankan', but also known as Cheikh Mouhammad Chérif, Cheikh Fanta-Mady, and Karamo Sékouba (ca. 1874-1955). ('Sharifula' is a locative construction, here used to designate the residence of the sharifs of Kankan.) Sekuba, whose immediate ancestors were also highly distinguished scholars, was widely known and respected throughout West Africa, travelling especially in Mali and Guinea. Often revered as a saint (Arabic wali, Manding wali or waliju), he helped keep the peace in Guinea in the turbulent years preceding independence. ${ }^{33}$

The contrast between Salimu's behaviour and the Muslim ideal is furthermore underscored by the status of Kankan as a major Muslim religious centre. Founded by Soninkespeaking Muslims, probably in the seventeenth century, it rapidly became famous for its learning as well as its commerce. Over time, these Soninke Muslims adopted the Maninka language, while converting some segments of the surrounding, erstwhile pagan, earlier settled Maninka population. ${ }^{34}$

Salimu's renunciation of Muslim standards of conduct is expressed through the following recurrent verses:

"The moon of Ramadan is on high,

but I, Salimu, am below."

and "Sekuba of Kankan is in Kankan,

but I, Salimu, am just here.”

According to former fellow church-goers, Salimu frequently made these statements in conversation.

The allusions to the sharif of Kankan also highlight another trait of Manding praise songs and narratives: they rarely evoke one person only. Although a song or story may be named for a given individual, several more are usually mentioned (and not just in the context of their relationships to the main protagonist). Thus, this narrative does double service as a praise song for Cheikh Mouhammad Chérif, mentioning his influence on the various populations of Guinea whom he helped to convert. Yet other individuals come in for praise: 'Paul', a major transporter, who owned a convoy of twelve cars; Dantuman, like Salimu a famous driver; 'Maurice', a friend of the narrator's; and more briefly, Madi Koné, a heavy drinker, and his mother, Na Koné, as well as Komanjan, another member of their crowd. ${ }^{35}$ 
To hear the narrator tell it, Kankan society in the late colonial period, especially in the 1950s on which he seems to focus, was non-judgemental. Neither Salimu's drinking, nor that of his acquaintance Madi Koné, nor even Salimu's relationships with prostitutes, is condemned. The local hospital's medical staff graciously accedes to Salimu's request to keep on drinking. The image of Kankan that emerges is almost idyllic - a city where people know each other, and persons of diverse social and ethnic origins intermingle. The 'Moor' 'Paul' - who is thus socially recognised as both 'Arab' and 'white', and whose family may have originated much further north - mixes socially with his Maninkaspeaking employees. 'Paul' and 'Maurice' are the French nicknames of individuals who have Muslim given names; such nicknames, which suggest a certain tolerance and even emulation of French culture, were popular, until perhaps a decade ago, in both Mali and Guinea. Indeed, the 1930 s to 1950 s are remembered as a golden age in Kankan, whose name is said to mean "welcome city" - a time remarkable both for cosmopolitan openness and strong local cultural affirmation, symbolised by the mamaya dance. ${ }^{36}$

Although at first blush, Salimu may appear to be an anti-hero, this is not the case. By Manding cultural standards, he has certain admirable traits. His good nature is widely recognised. As the lyrics dedicated to him repeatedly assert, "he wronged no man, he wronged no woman". He thus lives up to a certain humane - though not a specifically Muslim or Christian - ideal. Like the warrior heroes of Manding 'political epics', he has special, supernatural powers. Salimu's exceptional driving skills - like those of the lead driver, Dantuman - are due to a special magic (camu); and in Salimu's case, perhaps also to additional secret knowledge or gifts. It is only esoteric knowledge and supernatural agency that allows the two drivers to successfully navigate the bad roads of Mali and Guinea, and especially, cross their tumbledown bridges. Indeed, driving on poor roads or even any interurban driving - was until recently considered an heroic activity. I well remember how, in the 1980s and 1990s, a professional driver and transporter was met by a bard woman who sang his praises every time he travelled (at least once a week) the dirt road that then led from Bamako to the small town of Nossombougou (in the Koulikoro region; a distance of approximately $70 \mathrm{~km}$ ). ${ }^{37}$ Salimu thus conforms to the Manding image of the (mostly) benevolent hero with special powers. ${ }^{38}$

his relationship to Salimu; 'Paul', 10 lines; 'Maurice', 5 lines; and a line each for Madi Koné, his mother Na Koné, and Komanjan. Roger Labatut (1975) has compared the stringing of names in some Fulfulde oral poetry to that in the 'Ballade des dames du temps jadis' [Ballad of the ladies of yore] by the fifteenth-century French poet François Villon. Illegitimacy may constitute a subtext of this narrative. While in a substantial percentage of cases, husband and wife have the same 'honorific' or surname (especially in Guinea, where Maninka-speakers share a limited number of surnames), a child whose father has refused to recognise him may also bear his mother's name.

The stately mamaya dance, which may be performed by persons of all ages but especially by elder men, in full Muslim ceremonial dress and with their canes, may have been introduced from Bamako in the 1930s, but received its greatest elaboration and development in Kankan, where it is still very popular. See www.chantshistoiremande.free.fr. This dance deserves a musical, choreographic, and sociological study.

37 This road has since been replaced by a tarred highway.

38 Bird and Kendall (1980), in their groundbreaking article, insist on the esoteric powers and also on the aggressivity of Manding heroes. But the latter is true of only the most renowned political and military figures, and in most cases, even these are said to apply their sorcery and violence to ultimately benevolent ends (against recognised 
It should be needless to say that the reckless, drunken driving so humorously described in the present narrative would not be tolerated in Mali and Guinea today.

Bards, ordinary listeners, but also Salimu's friends and neighbours interviewed in Kankan suggested that the songs and narratives dedicated to him grew out of those he himself sang. Indeed, some words are remembered as Salimu's own (see above, p. 10). The bard Amadou Kouyaté, who knew Salimu personally, insists that all the episodes mentioned in his rendering are factual, in particular confirming that Salimu played the guitar and shared a hospital room with a mutual acquaintance called 'Maurice'. But it is perhaps more likely that a particular bard created some lines that were then taken up by other singers, who progressively created additional lines. The idea that the hero of a praise song is also the one who first performed it may correspond to a folk model of literary creation in Manding culture, for I have heard it advanced with respect to several works. In at least one case, which similarly concerns events from the 1950 s, this is demonstrably inaccurate. ${ }^{39}$ In any case, bards and listeners, as well as Salimu's friends and neighbours, are unanimous that songs about him began circulating in his lifetime. On the other hand, it is evident that the songs and stories continued to evolve after his death, since many versions (including those studied here) specifically refer to it.

Although Salimu himself could hardly be considered a model Christian or Muslim, the songs and narratives about him are anchored in a profoundly religious, specifically Islamic worldview. Salimu's very drunkenness is attributed to the Divine Will: "Salimu, it's an act of God!". Not a single musician nor listener perceived this assertion to be ironical (as it might seem to Western ears). Salimu's and Maurice's almost simultaneous accidents are similarly attributed to the Divine Will: "God had so decreed" (1.151 ). The beginning of the Islamic formula of religious witness, or shahada, "There is no God but God", occurs both in the narrative (four times) and in the song (once). Especially in the song (1. 17), one may receive the impression that Salimu's success as a driver is due to his sharif status. Arguably, God is a major protagonist of the song and narrative. ${ }^{40}$

The praises of Kankan's preeminent Muslim scholar figure prominently in both the narrative and the song. Drinking is explicitly criticised - though manifestly, prohibition is not backed by strong social sanctions. In other words: individuals may or may not conform to Islamic standards of behaviour, but no one doubts the existence of an omniscient and omnipotent Sovereign Lord, who intervenes actively in human affairs.

As with many other literary works transmitted by bards, the value of music and musical instruments is stressed, through allusions in the performance (narrative, 1. 156, 158, 189). The bard also projects himself into the narrative, describing events in which he claims to have participated: visiting Salimu and Maurice in the hospital, then later, praising Salimu in front of his friends $(1.154,188-191)$. This is both a way of vouching for the truth of the

enemies, for the general good).

39 With respect to 'Wulukoro', eyewitnesses claim that the drowning occurred very quickly, and that the girl could not have enunciated the pleas to the local shrines that figure so prominently in the song.

40 In some other Manding Islamic narratives, including 'Sunba', He even appears, in conformity with theological doctrines widely taught and accepted in West Africa, as the only true Agent (see Tamari 2005). 
story as told, and a means of creating a sense of personal familiarity between the bard and his listeners, and between the bard and the protagonists of the story. Pointing to Maurice's photo (1. 147) is yet another way of inducing such a sense of familiarity and affirming the truth of the narrative. The bard, in conformity with a widespread practice, also attempts to implicate his audience in the story, by apostrophising some of the persons present. Praise for living persons on appropriate occasions is indeed the stock-in-trade of most bards, and may well be the origin of some of Salimu's praise songs.

The narrative also manifests the centrality, in Manding culture, of being remembered in spite of and through death. The narrative expresses nostalgia for the departed - whose likes, it is implicitly claimed, are no longer to be found - and illustrates how a wellattended funeral is the sign of a life that, in certain respects at least, was well-lived. ${ }^{41}$

The poem conveys - through vividly recounted scenes, and the recurring lyric "Driver, wait for me!" - a sense of travelling on the decrepit country roads of Guinea and Mali in the mid-twentieth century. Not surprisingly given its subject, it is expressed in informal, everyday language - hardly a general characteristic of recent compositions. ${ }^{42}$ It includes a considerable number of French loanwords, almost all of which, however, refer to imported technology and institutions. ${ }^{43}$ Two specifically Guinean terms - common in that country, but rare in Mali - may be noted: kilasi (perhaps a loanword from French or another European language), which designates a glass bottle, typically one meant to hold alcoholic drinks; and matòo - an element of specifically bardic language, meaning 'to praise'. ${ }^{44}$

41 In some West African societies, the desire for a grandiose funeral can be a major spur to action. See the memoir Wangrin (Bâ 1992 [1973], pp. 143-184), and the ethnographic novels by Boni (1962) and Dembélé (1982).

42 Compare, for example, to the praise song (fasa) composed for a Segu teenager in 2002, which includes many archaic words and expressions, only familiar to bards (see Tamari 2007).

43 These are: akiselatèri (accélérateur, 'accelerator'), 1 occurrence; aksidan (accident), 1x; aksidante (accidenté, 'person who has had an accident'), 1x; bòn (from the interjection bon, 'well'), 1x; butèli (bouteille, 'bottle'), 3x; dirèkisòn (direction, 'steering wheel'), 2x; dòotòrò (docteur, 'medical doctor'), 1x; gitari (guitare, 'guitar'), 2x; gurupu (groupe, 'group'), 1x; kabini (cabine, 'passenger cabin'), 2x; kònwa (convoi, 'convoy'), 3x; maniwèli, (manivelle, 'starting handle'), 1x; lapitani (l'hôpital, 'the hospital'), 4x; manke (manquer, 'to lack'), 1x; mazi (magie, 'magic'), 1x; mètiri (maître, 'master, foreman'), 2x; mobili (automobile), 7x; paranti (apprenti, 'apprentice'), 4x; pasazelu (passager, 'passenger'), 2x; pòn (pont, 'bridge'), 8x; sarise (charger, 'to charge'), 1x; sarisi (charge), 1x; sofèri (chauffeur, 'driver'); sòròdasi (soldat, 'soldier'), 1x; turinela (tourner, 'to turn'), 1x; wèru (verre, 'drinking glass'), 1x. The French expression "la fin du mois" ("at the end of the month") also appears in this performance (1.133). The typically Guinean term kilasi (1. 93), which designates a usually glass bottle for alcoholic beverages, may also be a borrowing from French or another European language. The 56-line song version includes only two French loanwords: sofèrikè (from chauffeur, 'driver), 3x, and pòn (pont, 'bridge'), 2x, as well as the phrase 'la fin du mois'.

44 Lines 190-191 and 93 respectively. Matòo and the semantically equivalent (or very similar) term majamu are formed from the prefix ma- and the words tòo ('first name'; pronounced tògò in Bamana) and jamu ('honorific', 'clan name', 'surname'). 


\section{Conclusion}

Before encouraging the reader to enjoy Amadou Kouyaté's and Jekoriya Doumbia's renderings of 'Salimu' (transcribed and translated below), one may sum up the main points of this essay. Many longer narratives and songs have come into existence, over the course of the twentieth century, in the Maninka country of Mali and Guinea, based on the recollection of striking incidents involving individuals or (most typically) amorous couples. Most of these compositions display the stylistic characteristics that have been attributed to West African 'epics', including poetic language, alternation of sung and recited passages performed to instrumental accompaniment, and multi-generic qualities. However, these long, partially sung stories do not seem to correspond to a specific literary genre, as distinguished by the Manding themselves. Rather, they constitute a subset of several Manding literary genres. Maana and tariku seamlessly encompass heroic and sentimental, partially sung narratives, of various lengths, most of which are believed to be true. The songs and stories I recorded concern the period ca.1890-1990: this might be taken to suggest that they constitute an emergent literary genre, but it is more likely that such songs and stories have long been composed, only to be forgotten after several decades, or to lose their specific referents in time and space.

'Salimu' affectionately recalls the life and adventures of a Maninka Guinean driver, a Christian of Muslim sharifian descent, who lived ca. 1930-1991, and was much given to drink. Songs - and perhaps also stories - about him began to circulate in his lifetime, but continued to evolve after his death.

\section{References}

Bâ, Amadou Hampâté. L'Étrange destin de Wangrin ou Les Roueries d'un interprète africain. New ed. with a postface by the author. Paris: Editions 10/18, 1992. ( $1^{\text {st }}$ ed.: 1973.)

Bailleul, Charles. Dictionnaire bambara-français. $3^{\text {rd }}$ revised ed., Arabic etymologies by Michel Lagarde. Bamako: Donniya, 2007. ( $1^{\text {st }}$ ed.: 1980.)

Belcher, Stephen Paterson. Epic Traditions of Africa. Bloomington: Indiana University Press, 1999.

Bird, Charles S., "Oral Art in the Mande", pp. 15-25 in Carleton T. Hodge, ed., Papers on the Manding. Bloomington: Indiana University, 1971. (Indiana University Publications. African Series, 3.)

—, "Poetry in the Mande: Its Form and Meaning", Poetics 5(2), 1976: 89-100.

Bird, Charles S., Mamadou Koita and Bourama Soumaoro, eds. and translators. The Songs of Seydou Camara. Vol. I: Kambili. Bloomington, Indiana: African Studies Center, 1974.

Bird, Charles S., and Martha Kendall, “The Mande Hero”, pp. 13-26 in Ivan Karp and Charles S. Bird, eds., Explorations in African Systems of Thought. Bloomington: Indiana University Press, 1980.

Boni, Nazi. Crépuscule des temps anciens. Paris: Présence africaine, 1962. (Novel.)

Bornand, Sandra. Le discours du griot généalogiste chez les Zarma du Niger. Paris: Karthala, 2005.

Brévié, Jules, "À propos d'une chanson bambara", Annuaire et mémoires du Comité d'études historiques et scientifiques de l'Afrique occidentale française 1917: 217-222.

Camara, Brahima. Jägerliteratur in Manden. Bayreuth: Schultz und Stellmacher, 1998.

Camara, Seydou, "La tradition orale en question", Cahiers d'études africaines 36(4), n 144, 1996 : 763-790. 
Camara, Sirifo [bard narrator], and Sana Camara, ed. and translator. The Epic of Kelefaa Saane. Bloomington: Indiana University Press, 2010.

Camara, Sory. Gens de la parole. Essai sur la condition et le rôle des griots dans la société malinké. Paris: Karthala, 1992. ( $1^{\text {st }}$ ed.: Paris: Mouton, 1976.)

Camara, Sory. Paroles de nuit ou l'Univers imaginaire des relations familiales chez les Mandenka. Thesis for the doctorat d'État, Université de Paris V, 1981.

Cissé, Youssouf Tata, "Notes sur les sociétés de chasseurs malinké", Journal de la Société des Africanistes 34(1), 1964: 175-226.

Cissé, Youssouf Tata, ed. and translator. La grande geste du Mali: des origines à la fondation de l'empire. Paris: Karthala, 1988.

Cissé, Youssouf Tata, ed. and translator. Soundjata, la gloire du Mali. Paris: Karthala, 1991.

Cissé, Youssouf Tata. La confrérie des chasseurs malinké et bambara: mythes, rites et récits initiatiques. Paris: Karthala, 1994.

Condé, Boundiala, “L’Université traditionnelle coranique de Kankan, des origines à l'implantation coloniale". Mémoire de diplôme de fin d'études supérieures, Université de Kankan, Guinea, 1992.

Conrad, David C., with Soumaila Diakité. A State of Intrigue: The Epic of Bamana Segu according to Tayiru Banbera. Oxford: Oxford University Press for the British Academy, 1990.

Conrad, David C. Sunjata: A West African Epic of the Mande People. Cambridge, MA: Hackett Publishing, 2004.

Dembélé, Nagognimé Urbain. L'Inceste et le parricide. Bamako: Editions-Imprimeries du Mali, 1982. (Novel.)

Derive, Jean. Le fonctionnement sociologique de la littérature orale. L'exemple des Dioula de Kong (Côte d'Ivoire). Thesis for the doctorat d'État, Université de Paris III, 1986.

Derive, Jean, "Y a-t-il un style épique ?", pp. 97-132 in Jean Derive, ed. L'Épopée. Unité et diversité d'un genre. Paris: Karthala, 2002.

Derive, Jean. L'Art du verbe dans l'oralité africaine. Paris: L'Harmattan, 2012.

Derive, Jean, and Marie-Jo Derive, eds. and translators. Ntalen jula: contes dioula. Abidjan: CEDA, 1980.

Derive, Jean, and Gérard Dumestre, eds. and translators. Des hommes et des bêtes. Chants de chasseurs mandingues. Paris: Classiques africains, 2000. [Tales collected by Marie-José Derive.]

Diarra, Abdoulaye, and Veronika Görög-Karady, eds. and translators. Contes bambara du Mali. Paris: Publications orientalistes de France, 1979. 2 vols.

Doumbi-Fakoly (pseudonym). Mali-sadio : l'hippopotame de Bafulabé. Paris: Menaibuc, 2006.

Dumestre, Gérard, ed. and translator. La geste de Ségou, racontée par des griots bambara. Paris: Armand Colin, 1979.

Dumestre, Gérard, and Lilyan Kesteloot, eds. and translators. La prise de Dionkoloni, épisode de l'épopée bambara. Paris: Armand Colin, 1975.

Dumézil, Georges. Mythe et épopée. Paris: Gallimard, 1995. 3 vols. (1 ${ }^{\text {st }}$ complete edition: 1968-1973.)

Durán, Lucy, "Ngaraya: Women and musical mastery in Mali", Bulletin of the School of Oriental and African Studies 70(3), 2007: 569-602.

-, director. Growing into Music in Mali. Part. 1: Da Kali: The Pledge to the Art of the Griot. 1'26", 2012. Part 2: Do farala a kan: something has been added. 80', 2015. Film.

— , director. The Voice of Tradition: Bako Dagnon and Family. 28'. Extracted from Da Kali, 2012. Film.

Hale, Thomas A. Scribe, Griot, and Novelist: The Epic of Askia Mohammed. Gainesville: University of Florida Press, 1990.

Hale, Thomas A., and Aissata G. Sidikou, eds. and translators. Women's Songs from West Africa. Bloomington: Indiana University Press, 2014. 
Hellweg, Joseph. Hunting the Ethical State: the Benkadi Movement of Côte d'Ivoire. Chicago: The University of Chicago Press, 2011.

Hoffman, Barbara G. Griots at War: Conflict, Conciliation and Caste in Mande. Bloomington: Indiana University Press, 2000.

Huet, Michel. Les Hommes de la danse. Lausanne: Clairefontaine, 1954.

Innes, Gordon, ed. and translator. Sunjata: Three Mandinka Versions. London: School of Oriental and African Studies, 1974.

Innes, Gordon, ed. and translator. Kaabu and Fuladu: Historical Narratives of The Gambia. London: School of Oriental and African Studies, 1976.

Jansen, Jan. Siramuri Diabaté et ses enfants: une étude de deux générations de griots malinké. Utrecht, Bamako, 1991.

_ , "Narratives on Pilgrimage to Mecca: Beauty versus History in Mande Oral Tradition", pp. 249-267 in Toyin Falola and Christian Jennings, eds., Sources and Methods in African History: Spoken, Written, Unearthed. Rochester, N.Y.: Rochester University Press, 2003.

Jansen, Jan, Esger Duintjer, and Boubacar Tamboura, eds. and translators. L'Épopée de Sunjara, d'après Lansiné Diabaté de Kela (Mali). Leiden: CNWS Publications, 1995.

Jansen, Jan, Graeme Counsel, and Brahima Camara, "Sex, Drugs, and Female Agency: Why Siramori Diabaté's Song 'Nanyuman' Was Such a Success in Mali and Guinea”, Journal of West African History 4(1), 2018: 57-74.

Johnson, John William, "Yes, Virginia, There is an Epic in Africa", Research in African Literatures 11(3), 1980: 308-326.

Johnson, John William, ed. and translator. Son-Jara: The Mande Epic. Mandekan/English edition with notes and commentary. $3^{\text {rd }}$ rev. ed. Bloomington: Indiana University Press, 2003. ( $1^{\text {st }}$ ed.: 1986.)

Johnson, John William, Thomas A. Hale, and Stephen Paterson Belcher, eds. Oral Epics from Africa. Vibrant Voices from a Vast Continent. Bloomington: Indiana University Press, 1997.

Kaba, Lansiné. Cheikh Mouhammad Chérif et son temps, ou islam et société à Kankan, Guinée. Paris: Présence africaine, 2004.

Kedzierska-Manzon, Agnieszka. Chasseurs mandingues: violence, pouvoir et religion en Afrique de l'Ouest. Paris: Karthala, 2014.

Keïta, Cheick Mahamadou Chérif. Salif Keita, l'oiseau sur le fromager. Bamako: Le Figuier, 2001.

Keïta, Fodéba. Aube africaine et autres poèmes africains. Paris: Présence africaine, 1994.

Kesteloot, Lilyan, and Bassirou Dieng, eds. Les Épopées d'Afrique noire. Paris: Karthala, 1997.

Koné, Kassim. Bamana Verbal Art: An Ethnographic Study of Proverbs. Doctoral dissertation, Indiana University at Bloomington, 1997.

Labatut, Roger, ed. and translator. Chants de vie et de beauté, recueillis chez les Peuls nomades du Nord-Cameroun. Paris: Publications orientalistes de France, 1975.

Lagarde, Michel. Influences de l'arabe sur la langue bambara. Falajè, Mali: Centre d'étude de la langue bambara, 1988. Duplicated typescript.

Luneau, René. Les chemins de la noce: la femme et le mariage dans la société rurale au Mali. Thesis for the doctorat d'État, Université de Paris V, 1974.

Luneau, René. Chants de femmes au Mali. Paris: Luneau Ascot, 1981.

Monteil, Charles, "La légende de Ouagadou et l'origine des Soninkés", pp. 359-408 in Mélanges ethnologiques. Dakar: IFAN, 1953. (Posthumous publication.)

Niane, Djibril Tamsir. Soundjata, ou l'épopée mandingue. Paris: Présence africaine, 1960; trans. G.D. Pickett, Sundiata, an Epic of Old Mali. London: Longman, 1965.

Osborn, Emily Lynn. Our New Husbands are Here: Households, Gender, and Politics in a West African State from the Slave Trade to Colonial Rule. Athens, OH: Ohio University Press, 2011. 
Schulz, Dorothea. Perpetuating the Politics of Praise: Jeli Singers, Radios, and Political Mediation in Mali. Cologne: Rüdiger Köppe, 2001.

Seydou, Christiane, ed. and translator. Silâmaka et Poullôri, récit épique peul. Paris: Armand Colin, 1972.

Seydou, Christiane, ed. and translator. La Geste de Ham-Bodêdio ou Hama le Rouge. Paris: Armand Colin, 1976.

Seydou, Christiane, ed. and translator. Les guerres du Massina: récits épiques peuls du Mali. Paris: Karthala, 2014.

Seydou, Christiane, ed. and translator. Héros et personnages du Massina: récits épiques peuls du Mali. Paris: Karthala, 2014.

Sidibé, Fodé Moussa. L'Univers des chants de chasseurs au Mali. Bamako: EDIS, 2007.

Sissoko, Aboubacar Eros. Sadio et Maliba l'hippopotame: légende du Mali. Paris: L'Harmattan, 2005.

Sissoko, Fily Dabo. Les Jeux du destin. Paris: Jean Grassin, 1970. (Posthumous publication, author d. 1964.)

Tamari, Tal. Les castes au Soudan occidental: étude anthropologique et historique. Thesis for the doctorat d'État, Université de Paris-X Nanterre, 1988.

- Les castes de l'Afrique occidentale. Artisans et musiciens endogames. Nanterre: Société d'ethnologie, 1997.

— , “À la confluence des traditions orale et islamique: 'Soumba et Lansiné', pp. 235-266 in Jean Derive and Anne-Marie Dauphin, eds., Oralité africaine et création. Paris: Karthala, 2005. English translation, by the author, on pp. 941-969 of the associated CD-Rom: "At the Confluence of Oral and Islamic Traditions: the Story of "Sunba and Lansine".

— “'Hady': A Traditional Bard's Praise Song for an Urban Teenager”, Research in African Literatures 38(3), 2007: 77-111.

— , "Oral Literature as Moral Guide: 'Sunba' in Contemporary Media", Research in African Literatures 40(1), 2009: 57-73.

— , "From Oral Tradition to Film: Djély Mory Kouyaté's Lancinet et Soumba", The Global South 5(2), 2011: 107-120.

Thoyer-Rozat, Annik, ed. and translator. Chants de chasseurs du Mali. Paris: L'Harmattan, 1978. 3 vols.

Traoré, Karim. Le jeu et le sérieux: essai d'anthropologie littéraire sur la poésie épique des chasseurs du Mandé (Afrique de l'Ouest). Cologne: Rüdiger Köppe, 2000.

Travélé, Moussa. Proverbes et contes bambara: accompagnés d'une traduction française et précédés d'un abrégé de droit coutumier bambara et malinké. Paris: Paul Geuthner, 1923; reprinted 1977.

Wilks, Ivor, "The History of the Sunjata Epic: A Review of the Evidence", pp. 25-57 in Ralph A. Austen, ed., In Search of Sunjata. The Mande Oral Epic as History, Literature, and Performance. Bloomington: Indiana University Press, 1999.

www.chantshistoiremande.free.fr. "Chants et histoire du Mandé". Entries "Mamaya", "Mani Sajio", and "Salimun". Last consulted 18.10.2017. 


\section{Annexe}

\section{'SALIMU': TRANSCRIPTION AND TRANSLATION}

The verbal content of the performance that I recorded from Amadou Kouyate and his wife Jekoriya Doumbia, in January 2012 in the village of Dabadou near Kankan, Guinea, is presented here. The narrative version (12 minutes) is given first, then the briefer song version (3'30'), performed after it at my specific request.

In order to facilitate access to the rhetorical structure of the performance, the following code is observed in both the transcription and translation:

roman: spoken lines;

italics: sung lines.

'Paragraphing' and the determination of line boundaries are based on auditory criteria. Thus,- when two successive (grammatically and conceptually complete) sentences are enunciated without pause, they are placed on the same line;

- each instrumental interlude is marked by an empty (unnumbered, skipped) line.

The definition of lines and paragraphs is therefore substantially different from that which might have been obtained on strictly verbal or thematic criteria. It may be noted that the beginning (1. 29-35) of the first narrative passage (1. 29-69) is characterised by a long instrumental interlude between each line. Thematic breaks in the narration are also signalled by instrumental interludes, whereas this is not always the case for the transition from recitation to song (and vice-versa). The irregular length of the lines is typical of Manding oral poetry.

The identity of the performer(s) is indicated by initials at the beginning of the line, each time this identity changes: 'A' for Amadou Kouyaté; ' $\mathrm{J}$ ' for Jekoriya Doumbia; and ' $\mathrm{A}+\mathrm{J}$ ' for lines sung jointly by the two performers.

\section{NARRATIVE VERSION}

\section{Transcription}

\section{A: Salimu dòlò man nyi}

Salimu dòlò to, Ala nò le Salimu

dòlò man nyi ne, Salimu, n makònò

J: aa Hayidara, Loronbo Hayidara

$\mathrm{n}$ makònò, Ala nò le Hayidara

$\mathrm{n}$ makònò, Ala nò le Hayidara

aa Hayidara, Loronbo Hayidara

$\mathrm{n}$ makònò, Ala nò le Hayidara

n makònò, Ala nò le Hayidara 
10 kabini duniya danna serifu ma dòlò min fòlò, fò i kelen

kabini duniya danna, Hayidara ma dòlò min fòlò, fò i kelen

èe, Salimu jarabi dòlò man nyi

Salimu, $n$ makònò

èe, Salimu, dòlò to

A: Kisilu ma mori gwèrè lòn

o ye nò Sekuba le lòn,

Serifula, Hayidara

Maninkalu ma mori gwèrè lòn

olu bènnin Sekuba le ma, Serifula, Hayidara

20 ny'a wala Kankan sila la

sannin $\mathrm{n}$ di ne mòo manduman ye

n watò Kisiduu sila kan

$\mathrm{A}+\mathrm{J}$ : sannin ne di bèn $n$ mòo manduman di

A: i ma kè cè la yen, i ma kè muso la yan

bèe diyannamòo $\mathrm{n}$ makònò

$\mathrm{A}+\mathrm{J}$ : pòn karida, pòn ma kari

i la tambitò le

a baa tambi $n$ fa heee!

A: aha ! bòn n'i k'a mèn ko Salimu

30 serifu le tèrè

a k'a la denmisènya kè, k'a damina Loronbo

Salimu tèrè sofèri le di

a ka sofèriya kè Loronbo

a ka san yirika kè la a mobilibori la

o waati la

Solokakè dò tèrè Kankan

$\mathrm{o}$ tòo tèrè ko $\mathrm{Pol}$

kònwa tèrè o le bolo

n'i ka mèn ko kònwa

40 ka mobili tan ni fila

k'ayi bèe sarise

ka bò Kankan ka wa Konakiri

o mobili tan ni fila le tèrè taamala

$a$ fòkan tèrè o le ma ko kònwa

Salimu tèrè o le sofèriya la 
a filanan kèra jòn di ?

o le tèrè Dantuman di

aa! Dantuman, a bara sa

èe! Dantuman!

50 sofèri le tèrè o fana di.

Dantuman tèrè kuru mèn dò

camu tèrè ole bolo, mazi

a baa se pòn kòròn ma

a d'a fò a la pasazelu ma ko ayi nya masi !

i b'i nya masi

a baa dirèkisòn gwasi

i d'i yèrè ye pòn kò ma

Dantuman le tèrè o kèla

Salimu tèrè o le gurupu dò

Salimu ta tèrè mun di o dò

60 Salimu la camu tèrè mun ne di

a baa ban sarisi la

mobili tan ni kelen min ye sila kan

ale le tuunin a mètiri Dantuman na

ba Dantuman, camu tèrè o le bolo

ole tèrè sofèrikuntiiya la

a d'a fò Dantuman ma

ko mètiri k'i y'a fò sofèriyi nyè ko ayi wa ne nyè

ko ne tè wala fòlò

a a dòlò man nyi

70 aa n makònò, Ala nò le, ne taamanyòon

dòlò to

Ala le nò, Hayidara

$\mathrm{J}$ : Ala, $n$ watò Nzerekore sila la

sanni $\mathrm{n}$ di bèn $\mathrm{n}$ mòo manduman di

n watò Kisiduu sila la

sanni $\mathrm{n}$ di bèn $\mathrm{n}$ mòo manduman di

ne watò Kankan sila la

sanni $\mathrm{n}$ di bèn mòo manduman di

ka t'i la dindinya ma ka n'a s'i la mòobaya la

80 ka t'i la dindinya ma, Hayidara, ka n'a s'i la mòobaya la

i nya tè i ma kè kè la yan i ma kè muso la yan

sofèrikè n makònò

pòn karida, pòn ma kari

a baa tambitò le, la ilah

a bara tambi 
A: òhòn ! Salimu tolen o bolo le ma

$\mathrm{J}$ : dòlò man nyi

A: sofèri mòo tan ni kelen le ye nya lòn o di

a baa to kò o dò a di wa butèli saba san,

dòlò butèli saba.

90 a baa dòlò butèli saba san,

a di kelen nò k'a kun.

paranti min y'a bolo o lònnin o ye dòlò k'a la wèru kònò k'a d'a ma.

a baa ban dòlò kilasi kelen gwosila feewu.

a filanan, a d'o fana da ten.

a d'o tala min ka ban k'o tala kè a kuntè ma,

k'o fudufudu a kuntè ma.

a baa ban a nya lakola o la,

a d'a fò a la paranti k'i ye wa maniwèli don mobili da dò

o baa ban mobili turinela

100 mobili baa ban wulila

a sen ni taatò bolo la

paranti natò le k'a dòn kabini kònò

k'a sen ta k'a la akiselatèri_kan

k'a bolo ta k'a la dirèkisòn kan

ni ta banna kèla mobili_rò o dò

parantikè bi lòn kabini kò fè k'a lase

a mun ne fòla

a Salimu sila le nin,

Salimu sila bila, sila bila,

110 sofèrikè sila bila

lònfèn juman na tèrè

aa Salimu, aa n kaninyòon ne Salimu

i bara tambi, a bara tambi, a bara tambi

$\mathrm{A}+\mathrm{J}$ : Salimu bara na

A: a baa se mobili ma, a baa fò bibi !

o di sila jènkè, a b'i la o fudu fè, a di tambi

a baa se min fana ma, a b'i la o fudu fè, a di tambi.

$a$ baa se pòn kòròn ma, $a$ b'a fò a la pasazelu ma,

120 a da fò ko ayi nya masi han.

ayi b'i nya mayèlè la tuma pòn tètò la di,

èe, Salimu bara ban tambi.

aa Ala!

aa Salimu, sila bila,

Salimu sila bila, sila bila, sofèrikè bara tambi. 
lònfèn juman na tèrè?

baa dòlòsòngò baa manke a rò

a di na k'i lò Dantuman ma:

sofèrikè, i tè n julu,

130 mètiri i tè $n$ julu,

$\mathrm{i}$ tè $\mathrm{n}$ julu,

$\mathrm{A}+\mathrm{J}$ : i tè julu bèe diyannamòo, i tè julu,

la-fin-du-mois n n'a sara,

A: aa ne natò jiiya le ma, Hayidara.

a d'a fò ko wa ne Hayidara kelen le dòlò min na

a ko, Hayidara gwèrè tè.

a ko, sun karo ye san ma

ne Salimu, ne ye duu ma.

Kankan Sekuba ye Kankan,

140 a ko ne Salimu ye yan

aa Salimu, o k'a ta tile kè

sunkuduba le k'i bil'a kò.

a baa min ta yòrò min a d'o bila yen,

a to nin o le dò Salimu wodo kadida.

aa ! aksidan kèra Salimu le di, ka wodo kadi ka na a bila Kankan lapitani yan.

a wodo kadi ka n'a bila Kankan lapitani

$\mathrm{o}$ lon kama $\mathrm{n}$ dinyòonkè Morisi min tèrè di,

min foto ye nin di, o Morisi o fana lapitani o lon,

o tèrè sòròdasi le di, o bara aksidante.

150 o fana wodo bada kadi.

Ala bara kit'a la

Salimu lanni ne li fan kelen,

Morisi lanni ne li fan kelen.

an ne baa wili k'an watò b'òla fè.

gitari le ole bolo

a baa fò lapitani, ko fòli ka kè

Salimu tèrè a la gitari le fòla

$\mathrm{a}$ di sinnintò $\mathrm{a} \mathrm{d}$ 'a fò dòotòrò $\mathrm{ma}, \mathrm{k}$ 'ayi na $\mathrm{n}$ sòn dòlò la

160 ko $n$ ye min, ko jilòkò ye $n$ na.

an ne nanin jiiya le ma, Salimu.

aa ! Dukure n nò o le fò i ye,

$\mathrm{n}$ ko mòo ladeeba n'i yèrè tè kelen ye. 
duniya ye baro le di,

Dabadu Amadu le baro la.

Heee !

$\mathrm{J}$ : Ala, Kisilu ma mori gwèrè lòn,

olu bènnin Sekuba le ma Serifula.

Jaawara ma mori gwèrè lòn,

170 olu bènnin Sekuba le ma Serifula.

Hayidara bid'i la,

nba Salimu bara sa.

A: Salimu tolen o le dò

a lannin lapitani

dòlò sinni a kun kòdò

n'a ma dòlò min a tè se kuma la.

$a$ baa to o rò, a kènèya min kènin o rò,

a nana Dabadu yan ne.

aaa, Pol bara sa,

180 Komanjan bara sa.

aa ne nanin jiiya le la

$\mathrm{A}+\mathrm{J}$ : Hayidara bir'i la.

A: o lon tèrè Kònè Madi fana yan

aa $\mathrm{Na}$ Kònè den!

a fana y'i minna kojuguya.

ee, Ala!

ayi b'ayi nyòonna kun bon na o rò

$\mathrm{n}$ barin Pol d'a fò k'ayi wa fò

$\mathrm{n}$ barin Amadu ka na ni nkònin di

$190 \mathrm{n}$ baa sii o rò $\mathrm{n}$ di Salimu matòo,

n n'a matòo.

a a Salimu n makònò,

Salimu n makònò, $n$ makònò

ko serifukè, n makònò,

bèe diyannamòo $n$ makònò,

bè ni Ala tè, dòlò man nyi ne.

Salimu n makònò, $n$ makònò.

Salimu, Ala la baraka ye serifula, Hayidara.

$\mathrm{J}$ : a a Hayidara! Loronbo Hayidara

$\mathrm{A}+\mathrm{J}: n$ makònò Ala nò le Hayidara 
201 n makònò Ala nò le Hayidara

$\mathrm{J}$ : kabini duniya danna,

Hayidara ma dòlò min fòlò f'i kelen

kabini duniya danna,

serifu ma dòlò min fòlò f'i kelen

èe, la ilah, jarabi dòlò man nyi

la ilah, heee!

A: òo ! Salimu tonin o le rò òo ! fò ka na sii Kankan na,

210 aa ! fò ka saya se Salimu ma, a dòlò le minna.

a fana n'a la dòlò min,

a ma se cè ma, a ma se muso ma,

a ma mòo si da kòròbò.

a fana sanin lon mènna,

a yera kèra Kankan bèe la,

ko Salimu bara sa.

ka sukoya kè k'a kè,

duniya bèe k'a kè.

220 Salimu!

$\mathrm{J}:$ nba Salimu bara wa.

A: Salimu, a wakan ne ye kaburulon nò nin sinè.

$\mathrm{A}+\mathrm{J}:$ nba Salimu bara $\mathrm{sa}$

a bara wa

a bara wa sa

nba Salimu bara wa,

a bara wa,

a bara sa,

nba Salimu bara sa,

230 a bara $s a$,

a bara sa,

Salimu bara sa,

a bara sa.

A: a salimu ! a a Salimu !

aa! Ala nò le, Salimu,

aa! Ala nò le, Salimu. 
Salimu, Ala le faama di, la ilah.

heee!

$\mathrm{J}$ : Ala, Kisilu ma mori gwèrè lòn,

240 olu bènnin Sekuba le ma Serifula.

Gbèeselu ma mori gwèrè lòn,

olu bènnin Sekuba le ma Serifula.

Hayidara bir'i da.

A: Hayidara, serifu ma dòlò min fòlò, fò i kelen.

heee!

\section{Translation}

A: Salimu, drinking is bad.

Salimu, leave off alcohol. Salimu, it's an act of God.

Salimu, drinking is an evil. Salimu, wait for me!

J: Oh Haidara, Haidara of Loronbo!

Wait for me - it's an act of God, Haidara.

Wait for me - it's an act of God, Haidara.

Oh Haidara, Haidara of Loronbo!

Wait for me-it's an act of God, Haidara.

Wait for me - it's an act of God, Haidara.

10 Since the world was created, no sharif has indulged in alcoholic drinks, save you alone.

Since the world was created, no Haidara has indulged in alcoholic drinks, save you alone,

Salimu, inveterate drinking is bad.

Salimu, wait for me!

Salimu, give up drinking.

A: The Kissi have known no Muslim cleric,

except Sekuba

of Sharifula, Haidara!

The Maninka have known no other Muslim cleric:

they accepted Sekuba. Sharifula! Haidara!

20 I travelled the road to Kankan

in order to meet the person who pleases me. 
I am travelling on the road to Kissidugu

$\mathrm{A}+\mathrm{J}$ : in order to meet the one who pleases me.

A: You have wronged no man there, no woman here.

[You who are] appreciated by all, wait for me!

$\mathrm{A}+\mathrm{J}$ : Should the bridge tumble down, should it not tumble down,

you [the bridge] will be crossed.

He [Salimu] has crossed it!

A: Well, if you hear about Salimu,

30 [know that] he was a sharif [descendant of the Prophet].

He spent his childhood - he started out - in [the village of] Loronbo.

Salimu was a driver.

He was a driver in Loronbo.

For several years, he was a driver there.

At that time,

there was a certain Moor in Kankan,

who was called Paul.

He owned a convoy:

if you hear it said [that he had] a convoy,

40 [know that he had] twelve vehicles.

He would load them all up,

to go from Kankan to Conakry.

The twelve vehicles would travel [together],

that is what is known as a convoy.

Salimu was a driver by profession.

Who was his second [in fame]?

It was Dantuman!

Alas, Dantuman is no more.

Oh Dantuman!

$50 \mathrm{He}$ too was a driver.

He had a strong magic, called camu.

Whenever he would come to an old bridge, he would ask his passengers to shut their eyes.

You would close your eyes,

he would tap on the steering wheel,

and you would be over the bridge.

It's Dantuman who could do this. 
Salimu was a member of the group.

What was his specialty?

60 What was his camu?

Once they were loaded,

the twelve vehicles took to the road.

Salimu would follow his master, Dantuman.

Because Dantuman had camu,

he was the head driver.

Salimu would tell Dantuman:

"Master, tell the other drivers to go ahead,

I'm not leaving just yet."

Drinking is bad.

70 Wait for me! It's an act of God, oh my travel companion!

Leave off alcohol!

It's an act of God, Haidara!

J: By God, I'm travelling on the road to Nzerekore, in order to meet the person who pleases me.

I'm travelling on the road to Kissidugu, in order to meet the one who pleases me.

I'm travelling on the road to Kankan, in order to meet the person who pleases me.

Since your childhood and up to your adulthood,

80 since your childhood, Haidara, and throughout your adulthood,

you have wronged no man here, no woman here.

Driver, wait for me!

Should the bridge fall down, should the bridge not fall down,

it will be crossed - there is no God [but God] -

the bridge was crossed!

A: Salimu continued in this manner.

Drinking is bad.

Eleven drivers would precede him.

He would stay back in order to buy three bottles of beer,

90 three bottles of beer.

He would down the first bottle.

His apprentice would pour out his drink in a glass:

he would down the first bottle.

He would start out on the second bottle:

he would drink half, and pour the second half on his head,

he would splash it over his head, 
then he would wash his face with it.

He would ask his apprentice to turn on the car,

the apprentice would position the vehicle.

100 The vehicle would start up.

The apprentice would take Salim by the leg,

enter the cabin,

place Salimu's foot on the accelerator,

and his hands on the steering wheel.

The vehicle being ready,

the apprentice would stand in back of the cabin.

And what would he say?

"Salimu, here's the road,

Salimu, take the road, take the road,

110 driver, take the road."

What knowledge had he?

Oh Salimu, my beloved Salimu,

you have passed - he has passed, he has passed ahead.

$\mathrm{A}+\mathrm{J}$ : Salimu has come [up to the other vehicles].

A: When Salimu would come up to another vehicle, he would honk: "Beep, beep".

Salimu would come up to the vehicle, which would draw over: Salimu had overtaken

it.

And so with the others: Salimu would catch up and overtake them.

When he would arrive in front of an old bridge, he would tell his passengers:

120 "Shut your eyes tight!"

When they reopened them, they were across the bridge,

Salimu had crossed the bridge!

By God!

Salimu, take the road,

Salimu, take the road, take the road, driver take the road.

What knowledge did he have?

When he didn't have the money for beer,

he would go tell Dantuman:

"Driver, won't you lend me some money,

130 Master, won't you lend me some money,

won't you give me a loan,

$\mathrm{A}+\mathrm{J}$ : won't you lend to the one who is beloved of all, won't you lend me some money?

I'll pay you back at the end of the month."

A: I have come with hope, Haidara.

Salimu would declare: "I'm the only Haidara who drinks,

no other Haidara drinks." 
He would say: "The moon of Ramadan is on high,

but I, Salimu, am below."

"Sekuba of Kankan is in Kankan,

140 but I, Salimu, am just here."

Salimu was enjoying his youth,

until he was followed by a damsel who sells her charms.

As he was bringing her home,

Salimu broke his leg.

Salimu had had an accident, he broke his leg and was taken to the

Kankan hospital.

He broke his leg and found himself in Kankan hospital.

That day, my friend Maurice,

whose photo is right here, was also in the hospital.

He was a soldier, he had an accident,

150 he too had a broken leg.

God had so decreed.

Salimu lay in bed, on one side [of the room].

Maurice too lay in bed, on the [other] side [of the room].

We [, their friends,] went out to pay them a visit.

Salimu had a guitar,

he told the hospital personnel he wanted to play.

Salimu would play the guitar.

Sitting up, he told the doctor:

160 "Bring me a beverage,

that I may drink, I'm thirsty."

Salimu, I'm coming with hope.

Oh, Doukouré, indeed I've told you,

that yourself and the person who imitates you, they're not the same.

The world is conversation:

Amadu of Dabadu is talking now.

Heh!

J: By God, the Kissi have known no other Muslim cleric:

they accepted Sekuba of Sharifula.

The Diawara have known no other Muslim cleric:

170 they accepted Sekuba of Sharifula.

Haidara has gone to rest,

Salimu has passed away. 
A: Salimu continued so,

lying down in the hospital,

with beer by his bed.

If he doesn't drink, he can't speak!

Then, when he was well,

he came here, to Dabadu.

Alas, Paul is no more,

180 Komanjan is no more.

I come with hope.

$\mathrm{A}+\mathrm{J}$ : Haidara has gone to rest.

A: That day, Koné Madi was also there the child of Na Koné!

He, too, was a drinker -

by God!

As they all found themselves in the same room,

my 'uncle' Paul told them to call

'uncle' Amadu, that he should come with his ngòni.

190 I told the praises of Salimu -

let me praise him [now].

Oh Salimu, wait for me,

Salimu, wait for me, wait for me,

Descendant of the Prophet, wait for me,

you who are beloved of all, wait for me.

I swear by God, alcohol is an evil.

Salimu, wait for me, wait for me!

Salimu, God has blessed the descendants of the Prophet. Haidara!

\section{$\mathrm{J}$ : Oh Haidara, Haidara of Loronbo!}

$\mathrm{A}+\mathrm{J}$ : Wait for me - it's an act of God, Haidara.

201 Wait for me - it's an act of God, Haidara.

$\mathrm{J}$ : Since the world was created,

no Haidara has indulged in drink, save you alone.

Since the world was created,

No sharif has indulged in alcohol, save you alone.

By God, inveterate drinking is bad.

There is no God [but God]!

A: Salimu persisted in this way,

until he came to settle in Kankan,

210 until he passed away. 
He continued drinking, yet in spite of this,

he wronged no man, he wronged no woman.

He never provoked anyone.

The day he died,

all Kankan was well aware

of his passing.

His funeral was greatly attended,

all participated.

220 Salimu!

J: But Salimu has gone away.

A: Salimu, one hears the sound of his funeral.

$\mathrm{A}+\mathrm{J}$ : But Salimu has passed away.

He has gone away,

he has gone away indeed.

Salimu has gone away,

he has gone away,

he has passed away.

Salimu has passed away,

230 he has passed away,

he has passed away.

Salimu has passed away,

he has passed away.

A: Oh, Salimu! Oh, Salimu!

It's an act of God, Salimu!

It's an act of God, Salimu!

Salimu, God is the Ruler, there is no God [but God].

Heh!

J: By God, the Kissi have known no other Muslim cleric:

240 they agreed upon Sekuba of Sharifula.

The Guerze have known no other Muslim cleric:

they agreed upon Sekuba of Sharifula.

Haidara has gone to rest.

A: Haidara, no sharif has indulged in alcohol, except for you only.

Heh! 


\section{SONG VERSION}

\section{Transcription}

J: a Hayidara, Loronbo Hayidara

$\mathrm{n}$ makònò, Ala nò le Hayidara

$\mathrm{n}$ makònò, Ala nò le Hayidara

aa Hayidara, Loronbo Hayidara

n makònò, Ala nò le Hayidara

$\mathrm{n}$ makònò, Ala nò le, aan !

kabini duniya danna, serifu ma dòlò min fòlò, fò i kelen

kabini duniya danna, Hayidara ma dòlò min fòlò, fò i kelen

9 Ala, $n$ watò Kankan sila la

$\mathrm{A}+\mathrm{J}$ : sanni $n$ bènnin mòo manduman di

$\mathrm{J}$ : Ala, $n$ watò Nzerekore sila la

$\mathrm{A}+\mathrm{J}$ : sanni $n$ bènnin mòo manduman di

ka t'i la dindinya ma, ka n'a s'i la mòobaya la

ka t'i la dindinya ma, ka n'a s'i la mòobaya la

i ma kè kè la yan, i ma kè muso la yan

$\mathrm{J}$ : sofèrikè $n$ makònò

$\mathrm{A}+\mathrm{J}$ : pòn karida, pòn ma kari, serifu tambitò le

la ilah, a bara tambi

$\mathrm{n}$ kaninyòon ani $\mathrm{n}$ wèrè nyòon Salimu, Hayidara

20 A: Ala la, baraka ye serifula, n makònò

sofèrikè, i tè n julu,

sofèrikè, $i$ tè $n$ julu,

$\mathrm{i}$ tè $\mathrm{n}$ julu,

bèe diyannamòo, $\mathrm{i}$ tè $\mathrm{n}$ julu,

$\mathrm{A}+\mathrm{J}$ : la-fin-du-mois, n n'a sara

$\mathrm{J}$ : nba Hayidara bara wa

A: nba Hayidara bara na

aa! n nalen ni jiiya le ma

Kisilu ma mori gwèrè lòn

30 olu bènnin Sekuba le ma

Serifula! Hayidara!

n ko Gbèeselu ma, olu ma mori gwèrè lòn, 
olu bènnin Sekuba le ma

Serifula ! Hayidara!

J: aa, Salimu! Loronbo Salimu

AJ: n makònò, Ala nò le, Salimu!

n makònò, Ala nò le, Salimu!

A: Salimu, n majarabi, Salimu,

$\mathrm{n}$ makònò

40 J: aa Salimu, Loronbo Salimu!

$\mathrm{n}$ makònò, Ala nò le, Salimu !

n makònò, Ala nò le, Salimu !

kabini duniya danna, Hayidara ma dòlò min fòlò,

fò i kelen

kabini duniya danna, serifu ma dòlò min fòlò,

fò i kelen

Ala, Kisilu ma mori gwèrè lòn, olu bènnin Sekuba le ma, Hayidara!

Gbèeselu ma mori gwèrè lòn,

50 olu bènnin Sekuba le ma, Hayidara!

$\mathrm{n}$ makònò,

Hayidara !

nba Hayidara bara wa!

a bara wa

a bara wa

56 Hayidara bara wa!

\section{Translation}

\section{J: Oh Haidara, Haidara of Loronbo!}

Wait for me - it's an act of God, Haidara.

Wait for me - it's an act of God, Haidara.

Oh Haidara, Haidara of Loronbo!

Wait for me - it's an act of God, Haidara.

Wait for me - it's an act of God.

Since the world was created, no sharif has indulged in alcoholic drinks, save you alone.

Since the world was created, no Haidara has indulged in alcoholic drinks, save you alone.

9 By God, I'm travelling on the road that leads to Kankan, 
$\mathrm{A}+\mathrm{J}$ : so that I may meet the one who pleases me.

$\mathrm{J}$ : By God, I'm travelling on the road to Nzerekore,

$\mathrm{A}+\mathrm{J}$ : so that I may meet the one who pleases me.

Since your childhood and up to your adulthood,

since your childhood and up to your adulthood,

you have wronged no man here, you have wronged no woman here.

J: Driver, wait for me!

$\mathrm{A}+\mathrm{J}$ : Should the bridge fall down, should the bridge not fall down, the sharif will cross it.

There is no God [but God], he has crossed it!

My beloved Salimu, my other self! Haidara!

20 A: By God, the descendants of the Prophet are blessed-wait for me!

Driver, won't you lend me some money,

driver, won't you make me a loan?

Driver, won't you lend me some money,

won't you lend

to the one who is beloved of all, won't you lend me?

$\mathrm{A}+\mathrm{J}$ : At the end of the month, I'll pay you back.

\section{$\mathrm{J}$ : Haidara has gone away,}

A: Haidara has come back.

Ah! I'm coming with hope.

The Kissi have known no other Muslim cleric,

30 they agreed upon Sekuba.

Sharifula! Haidara!

I say, about the Guerze, they have known no other Muslim cleric, they agreed upon Sekuba.

Sharifula! Haidara!

$\mathrm{J}:$ Ah, Salimu! Salimu of Loronbo!

$\mathrm{A}+\mathrm{J}$ : Wait for me - it's an act of God, Salimu.

Wait for me - it's an act of God, Salimu.

Salimu, I appreciate you - Salimu, wait for me.

40 J: Ah Salimu, Salimu of Loronbo!

Wait for me - it's an act of God, Salimu.

Wait for me - it's an act of God, Salimu. 
Since the world was created, no Haidara has indulged in drink, save you alone.

Since the world was created, no sharif has indulged in drink, save you alone.

By God, the Kissi have known no other Muslim cleric, they accepted Sekuba. Haidara!

The Guerze have known no other Muslim cleric, 50 they accepted Sekuba. Haidara!

Wait for me,

Haidara!

But Haidara has gone away!

He's gone away,

gone away,

Haidara has gone away. 